\title{
Risk of adverse pregnancy outcomes and seroprevalence for brucellosis in pregnant women exposed to goats or raw goat products in southern Thailand: a prospective cohort study
}

\author{
Kan Kledmanee ${ }^{1}$, Tippawan Liabsuetrakul ${ }^{1 *}$ (D) and Somporn Sretrirutchai ${ }^{2}$
}

\begin{abstract}
Background: Pregnant women infected with brucellosis have been shown to have higher odds of having been exposed to goats and raw goat products and adverse pregnancy outcomes. However, information on these associations in asymptomatic pregnant women is limited, particularly in the brucellosis-endemic areas. This study aimed to assess the association of a history of exposure to goats and/or raw goat products and the serological status of anti-Brucella abortus immunoglobulin $\mathrm{G}(\mathrm{lgG})$ with adverse pregnancy outcomes among pregnant women, and explore factors associated with having exposure to goats and/or raw goat products.

Methods: A prospective cohort study was conducted among pregnant women from July 2015 to July 2016 at Songkhla province in southern Thailand. All pregnant women who came for antenatal care (ANC) visits were approached. Blood samples from the women who agreed to participate were randomly tested for anti-Brucella abortus IgG. The women were then followed for adverse pregnancy outcomes.

Results: Of 666 pregnant women, the majority (74.4\%) were aged 20-34 years and Muslim (89.2\%), 30.6\% indicated exposure to goats or raw goat products, and $17.3 \%$ had adverse pregnancy outcomes. Women rearing goats at home or having neighbors rearing goats were more likely to be exposed to goats or raw goat products by cutaneous contact. Of 465 women having a blood test, 3.7\% had seropositive results for anti-Brucella abortus lgG. No association with adverse pregnancy outcomes was found in the women reporting any exposure to goat and raw goat products. Having the first ANC visit at the first trimester and history of preterm birth or low birth weight newborn were independent risk factors of adverse pregnancy outcomes. Women who had positive serological results were more likely to have a history of drinking raw goat milk than those who had negative results significantly.

Conclusions: Although no association between past exposure with goats and raw goat products and adverse pregnancy outcomes was found, women with past exposure showed positive anti-Brucella abortus IgG. Counseling on avoiding consumption of raw goat milk would be beneficial to prevent goat-related infection in pregnant women in this area.
\end{abstract}

Keywords: Adverse pregnancy outcome, Brucellosis, Exposure, Goat, Pregnant women, Raw goat products

\footnotetext{
* Correspondence: Itippawa@yahoo.com

${ }^{1}$ Epidemiology Unit, Faculty of Medicine, Prince of Songkla University,

Songkhla, Thailand

Full list of author information is available at the end of the article
}

(c) The Author(s). 2019 Open Access This article is distributed under the terms of the Creative Commons Attribution 4.0 International License (http://creativecommons.org/licenses/by/4.0/), which permits unrestricted use, distribution, and reproduction in any medium, provided you give appropriate credit to the original author(s) and the source, provide a link to the Creative Commons license, and indicate if changes were made. The Creative Commons Public Domain Dedication waiver (http://creativecommons.org/publicdomain/zero/1.0/) applies to the data made available in this article, unless otherwise stated. 


\section{Background}

Adverse pregnancy outcomes, including abortion, stillbirth, preterm birth, and low birth weight, are common obstetric conditions indicating the quality of maternal and child services worldwide [1,2]. Risk factors associated with these adverse outcomes through various mechanisms include maternal age, parity, body mass index, nutrient intake, stress and infections [3]. One of the risk factors for certain types of infections is various common pathogens being passed from infected animals to pregnant women, including Listeria monocytogenes, Coxiella burnetti, Brucella melitensis, Brucella abortus, Chlamydia trachomatis, Chlamydia abortus, and Chlamydia pneumoniae [4-7]. A study from Egypt showed significantly higher incidences of abortion (27\% vs $15 \%)$ and intrauterine fetal death ( $13 \%$ vs $4 \%)$ in women with a positive titer of brucellosis compared to women with a negative titer [8]. Two in vitro studies showed that Brucella replicate in human trophoblasts and interfere with invasive capacity of extravillous trophoblast-like cells and produce proinflammatory responses which may contribute to pregnancy complications $[9,10]$.

Excretions from infected animals through urine, feces, and milk can contain zoonotic infectious agents which can be accidentally inhaled, ingested, or passed through direct contact via the skin. Many daily or occupational activities can involve potential pathogens as biological risks, either at home or through animal husbandry [11, 12]. For pregnant women, contact with animals, handling raw animal products, and consumption of undercooked meat or unpasteurized dairy products have been shown to be risk factors for adverse pregnancy outcomes among those living in zoonosis endemic areas $[8,11,13,14]$.

Brucellosis, caused by Brucella sp., is a zoonotic infection which can affect human reproductive health. The clinical manifestations of brucellosis can involve many systems and nonspecific manifestations such as fever, sweating, anorexia, weight loss, headache, fatigue, malaise, arthralgia and back pain [15]. It has been associated with spontaneous abortion, fetal death, preterm birth, and low birth weight $[8,16,17]$. Various studies have reported the seroprevalence of brucellosis among pregnant women with a history of adverse pregnancy outcomes from 1.8 to $25.0 \%[18,19]$. However, the evidence of an association between Brucella seropositivity and adverse pregnancy outcomes is still inconclusive from previous studies which may be due to the use of various serological tests such as the Rose Bengal Plate Test, tube agglutination or an enzyme-linked immunosorbent assay and the cross-sectional study was applied in most studies $[8,16,20,21]$. To evaluate a causal relationship between brucellosis seropositivity and adverse pregnancy outcomes, a prospective study using serological diagnostic tool with high specificity for antibodies testing should be carried out.

Previous studies on the history of exposure to animals and/or raw animal products prior to or during pregnancy and the association with adverse pregnancy outcomes have focused on symptomatic rather than asymptomatic pregnant women $[16,17,22]$. The time from exposure to an infected animal to the detection of seropositivity in humans can vary from a week up to 10 years which can be indicated acute, chronic or previous infection [23]. Brucellosis can be diagnosed when the serological results are positive which is more common in symptomatic than asymptomatic individuals [23-25].

In Thailand, the rate of spontaneous abortion was $6.9 \%$ of total pregnancies [26], and rates of preterm and low birth weight newborns were $13.7 \%$ and $8.4 \%$, respectively [27]. However, to date in Thailand there have been no studies examining brucellosis in pregnant women and to what extent it might be related to adverse pregnancy outcomes. Understanding the factors associated with exposure to animal or raw animal products and the relation of such exposure to the pregnancy risk of brucellosis would be useful for health education and promotion [28]. This study aimed (i) to assess the association of a history of exposure to goats and/or raw goat products and the serological status of anti-Brucella abortus immunoglobulin $\mathrm{G}$ with adverse pregnancy outcomes among pregnant women, and (ii) to explore factors associated with having exposure to goats and/or raw goat products among pregnant women.

\section{Methods}

\section{Study design and setting}

This prospective cohort study was conducted in 4 of the 16 districts of Songkhla province in southern Thailand, where meat and dairy goat production associated with the Thai Muslim communities is commonplace for household consumption and marketing. Songkhla province has been reported as the highest endemic area of animal brucellosis in southern Thailand and goats were identified to be the most infected animal during brucellosis outbreaks in this area $[29,30]$.

Four districts, Thepa, Chana, Saba Yoi, and Na Thawee, were chosen for the study because the registered number of households rearing goats were in the top five provincial rankings, accounting for up to $22 \%$ of all goats being raised [30]. Antenatal care (ANC) for pregnant women in the study district is provided in the Primary Care Units of a district hospitals and the Health Promoting Hospitals in the subdistrict level of each district. Information on ANC and delivery of pregnant women within the districts is routinely recorded and monitored by the district hospital. 


\section{Participants}

In Thailand, all pregnant women are encouraged to attend ANC which is provided by skilled attendants, with the first visit before 12 weeks of gestation as recommended by the World Health Organization (WHO). The number of ANC visits for low-risk pregnancies is at least 5 times: <12, 16-20, 24-28, 30-34, and 36-40 weeks are the normal recommendation. For this study, pregnant Thai women aged 15-49 years who had a gestational age of 28 weeks or less coming for their first ANC visit at the study hospitals during July 2015-July 2016 and who planned to give birth at the responsible district hospital were included.

\section{Data collection}

All eligible pregnant women presenting as noted above were informed about the study and invited to participate. After agreeing and signing the consent form, they were interviewed using a structured questionnaire and a blood sample for serological testing was taken. All women were followed until the completion of the study. The pregnancy outcomes were recorded by the health personnel who provided ANC.

\section{Tools and measurements}

The structured questionnaire used in the study was divided into 4 main parts: socio-demographic and family characteristics, obstetric history, including previous history of one or more adverse pregnancy outcomes in prior pregnancies, types of home animals, and history of exposure to goats and raw goat products. The questionnaire was completed within $10-15 \mathrm{~min}$ by either a research assistant or the pregnant women themselves on the date of their first ANC visit.

Three-mL blood samples were collected in plain tubes separately from the ANC routine blood test and transported to the laboratories of the district hospitals. The serum was separated from the clotted blood samples and stored at $-20{ }^{\circ} \mathrm{C}$. Due to cost restrictions, 500 test kits were prepared that these samples were sufficient to detect the proportion of positive titer at $5 \%$. The serum samples to be tested were chosen by simple random sampling using computer-generated random numbers, and tested for anti-Brucella abortus immunoglobulin G (IgG) by enzyme-linked immunosorbent assay (ELISA) using a commercial ELISA anti-Brucella abortus IgG kit manufactured by EUROIMMUN (Lübeck, Germany) at the Immunology and Virology Unit laboratory at Songklanagarind Hospital, Songkhla province. The sensitivity and specificity of the kit were $78.0 \%$ and $98.0 \%$, respectively. Following the recommendations of the manufacturer without adjustment, a value of 22 relative units $/ \mathrm{mL}$ or more was considered as positive. This cut-off level of
IgG from a single serum sample cannot differentiate between acute and chronic infection.

\section{Variables \\ Outcome measures}

The occurrence of any adverse pregnancy outcomes defined as abortion, stillbirth, preterm birth and low birth weight newborn was the main outcome measure. Abortion was defined as premature expulsion of an embryo or fetus at gestational age of 23 weeks or less or weighing less than $500 \mathrm{~g}$. Stillbirth was defined as birth of a baby showing no signs of life. Preterm birth was a birth before 37 completed gestational weeks and newborn weighing $2500 \mathrm{~g}$ or less was classified as low birth weight newborn.

\section{Exposure status and independent variables}

Having a history of any exposure to goats or raw goat products one or more times in their lives before the serology blood test at the first ANC visit was the criterion used for categorizing the pregnant women into unexposed and exposed groups. The exposure was then stratified by route of exposure as either cutaneous contact or consumption. Cutaneous contact was defined as a history of physical contact with a live goat or any of the various activities involved with rearing goats such as cleaning goat shelters, helping with goat births, or disposing goat carcasses, or otherwise having physical contact with raw goat meat or milk including slaughtering, meat cutting or milking. Consumption included a history of consumption of raw goat meat or milk.

Independent variables recorded were demographic characteristics, household environment factors related to animals, obstetric details of the current pregnancy, and previous history of adverse pregnancy outcomes. The demographic characteristics were age, religion, education attainment and occupation. Household environment factors related to animals included having home animals and types of home animals. Obstetric details of the current pregnancy were gestational age at first ANC, gravida, and parity. Previous history of adverse pregnancy outcomes defined as abortion, stillbirth, preterm birth and low birth weight newborn.

\section{Sample size calculation}

The comparison of two proportions formula was used for sample size calculation, and based on a literature review that reported the prevalences of adverse pregnancy outcomes among pregnant women with and without livestock exposure the required percentages were 20 and $10 \%$, respectively [31]. Given a two-tailed alpha of $5 \%$ and a power of $80 \%$ to detect this difference, at least 169 exposed and 338 unexposed pregnant women (using a ratio of 1 to 2 as found from a pilot study) were needed. 
After 15\% exclusion and assuming a $15 \%$ loss to follow-up rate and $10 \%$ non-response rate, a total of 663 women were required.

\section{Data analysis}

All data were verified by double entry using EpiData version 3.1. Statistical analysis for both subgroups was performed with $\mathrm{R}$ version 3.5.0 and the Epicalc version 3.4.3.0 package. Distribution of exposure and adverse pregnancy outcomes were calculated descriptively in percentages. Associations between demographic characteristics, household environment, obstetric information, and exposure to goats and raw goat products and adverse pregnancy outcomes were analysed using univariate analysis and multiple logistic regression. A $p$ value of 0.2 was used to include the factors in the regression analysis. A $p$ value of 0.05 was set as the significance level.

\section{Results}

Of 1773 pregnant women attending their first ANC visit during the study period, 1011 women with more than
28 weeks of gestational age, who were non-Thai, who planned to give birth at a hospital other than the responsible district hospital, or unable to make decision to participate our study at date of first ANC visit were not eligible for the study, leaving a total of 762 women who fulfilled the criteria and were invited to participate in the study. All the women who were invited agreed to participate in the study. A flow diagram of the study is shown in Fig. 1. At the end of the follow-up period, 666 women were analysed for association between exposure status and occurrence of adverse pregnancy outcomes, and 465 for the brucellosis seroprevalence.

Table 1 presents the women's demographic characteristics, obstetric information, and household environment information. The distributions of those characteristics and information among all women $(n=666)$ and women with blood tests $(n=465)$ were similar. The ages of the 666 women ranged from 15 to 44 years (mean $\pm \mathrm{sd}$. = $27.4 \pm 6.3$ years), with most aged $20-34$ years. Most were Muslim, with education attainment of secondary school,

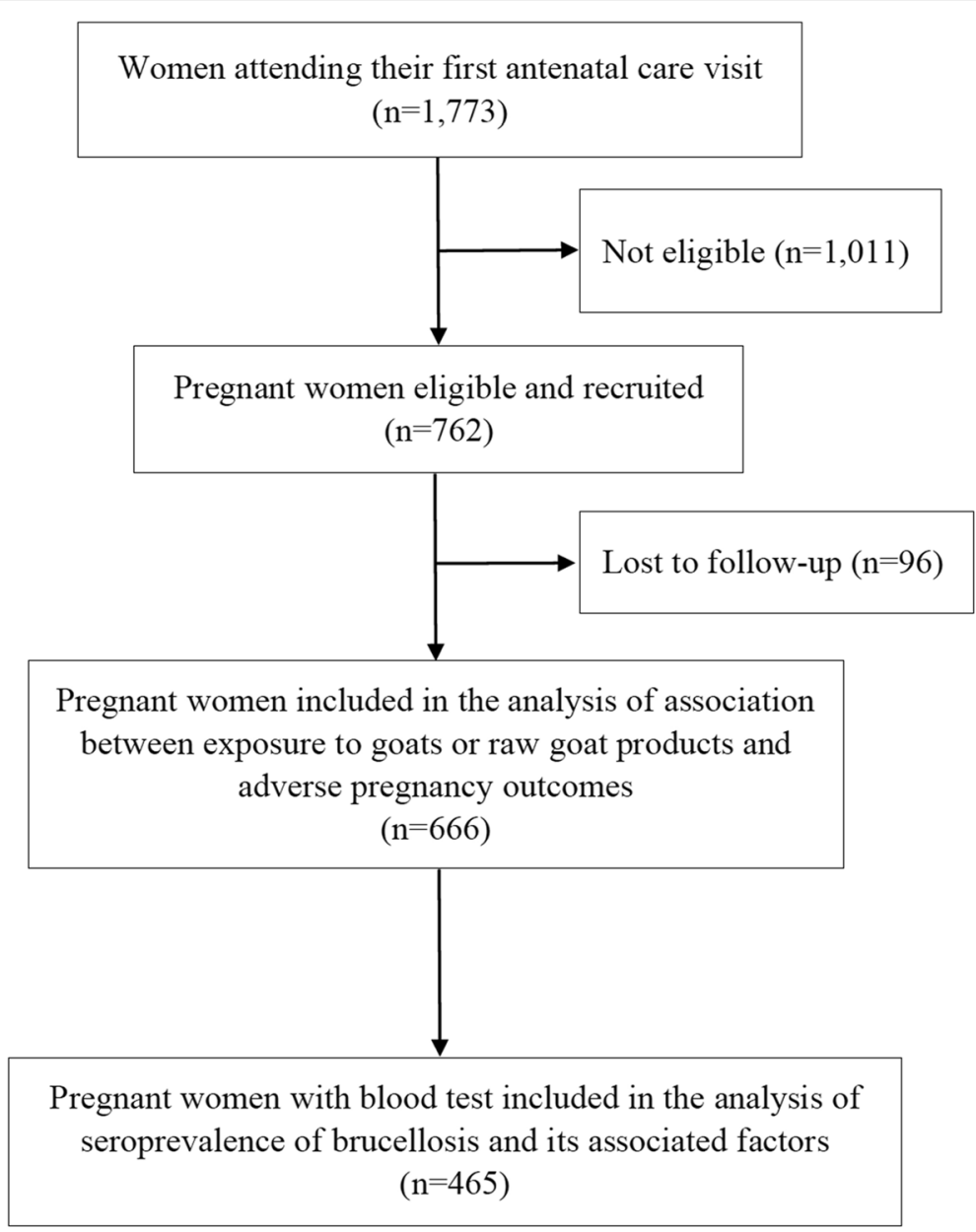

Fig. 1 Flow diagram of the study 
Table 1 Demographic characteristics, obstetric information, and household environments of the study women

\begin{tabular}{|c|c|c|c|}
\hline \multirow[t]{2}{*}{ Characteristic } & \multirow{2}{*}{$\begin{array}{l}\text { All pregnant women } \\
(n=666) \\
n(\%)\end{array}$} & \multirow{2}{*}{$\begin{array}{l}\text { Pregnant women with } \\
\text { blood test }(n=465) \\
\mathrm{n}(\%)\end{array}$} & \multirow[t]{2}{*}{$p$ value } \\
\hline & & & \\
\hline \multicolumn{4}{|l|}{ Demographic characteristics } \\
\hline Age group, in years & & & 0.956 \\
\hline $15-19$ & $74(11.1)$ & $51(11.0)$ & \\
\hline $20-34$ & $496(74.5)$ & $344(73.9)$ & \\
\hline $35-49$ & $96(14.4)$ & $70(15.1)$ & \\
\hline Religion & & & 0.060 \\
\hline Muslim & $594(89.2)$ & $431(92.7)$ & \\
\hline Buddhist or others & $72(10.8)$ & $34(7.3)$ & \\
\hline Education & & & 0.979 \\
\hline Primary school or lower & $178(26.7)$ & $123(26.5)$ & \\
\hline Secondary school & $375(56.3)$ & $261(56.1)$ & \\
\hline College/university & $113(17.0)$ & $81(17.4)$ & \\
\hline Occupation & & & 0.692 \\
\hline Agricultural worker or laborer & $351(52.7)$ & $237(50.9)$ & \\
\hline Salesperson, teacher, clerk, or technician & $164(24.6)$ & $125(26.9)$ & \\
\hline Housewife & $151(22.7)$ & $103(22.2)$ & \\
\hline Personal monthly income, in USD & & & 0.847 \\
\hline $0-184$ & $391(58.7)$ & $265(57.0)$ & \\
\hline $185-368$ & $213(32.0)$ & $155(33.3)$ & \\
\hline$\geq 369$ & $62(9.3)$ & $45(9.7)$ & \\
\hline \multicolumn{4}{|l|}{ Obstetric information } \\
\hline Gestational age & & & 0.418 \\
\hline $1^{\text {st }}$ trimester $(<14$ weeks $)$ & $560(84.1)$ & $400(86.0)$ & \\
\hline $2^{\text {nd }}$ trimester (14-28 weeks) & $106(15.9)$ & $65(14.0)$ & \\
\hline Gravida & & & 0.909 \\
\hline Primi-gravida & $178(26.7)$ & $119(25.6)$ & \\
\hline Multigravida & $427(64.1)$ & $302(64.9)$ & \\
\hline Grand-multigravida & $61(9.2)$ & $44(9.5)$ & \\
\hline Parity & & & 0.976 \\
\hline Nulliparity & $198(29.7)$ & $136(29.2)$ & \\
\hline Primiparity & $241(36.2)$ & $171(36.8)$ & \\
\hline Multiparity & $227(34.1)$ & $158(34.0)$ & \\
\hline Having history of abortion & $103(15.5)$ & $81(17.4)$ & 0.381 \\
\hline Having history of stillbirth & $11(1.7)$ & $7(1.5)$ & 0.847 \\
\hline Having history of preterm birth or low birth weight & $84(12.6)$ & $66(14.2)$ & 0.441 \\
\hline \multicolumn{4}{|l|}{ Household environment } \\
\hline Having cats, dogs, or rabbits & $309(46.4)$ & $218(46.9)$ & 0.872 \\
\hline Having chickens or ducks & $199(29.9)$ & $141(30.3)$ & 0.873 \\
\hline Having other birds & $147(22.1)$ & $104(22.4)$ & 0.907 \\
\hline Having goats & $103(15.5)$ & $92(19.8)$ & 0.059 \\
\hline Having cattle & $20(3.0)$ & $19(4.1)$ & 0.326 \\
\hline Having neighbor rearing goats & $243(36.5)$ & $172(37)$ & 0.863 \\
\hline
\end{tabular}


agriculture workers and laborers and low personal monthly income. More than $80 \%$ of them had their first ANC visit at first trimester and one-fourth were primigravida. Three-fourths of women came for the first visit before 12 weeks of gestation as the national recommendation. One-fourth had a history of adverse pregnancy outcomes, of which abortion was the most common followed by preterm birth or low birth weight newborn and then stillbirth. Two-thirds of them had home animals and one-third reported that they had a neighbour rearing goats nearby their household.

Of 666 women, $204(30.6 \%)$ had a history of any exposure to goats or raw goat products of which $64.7 \%$ of them were exposed via cutaneous contact and $36.8 \%$ of them were exposed by the consumption of raw goat products. Of the 465 women who had complete data of exposure and serum samples, 17 (3.7\%) had positive serological results for anti-Brucella abortus IgG. Women who had positive serological results were more likely to a history of drinking raw goat milk than those who had negative results $(6 / 17,35.3 \%$ vs $42 / 448,9.4 \%, p=0.005)$, respectively.

One hundred and fifteen women (17.3\%) had had one or more adverse pregnancy outcomes, which were abortion in $42(42 / 115,36.5 \%)$, stillbirth in $2(2 / 115,1.8 \%)$ and preterm birth or low birth weight in $71(71 / 115$, $61.7 \%)$. Table 2 shows factors associated with occurrence of any adverse pregnancy outcome among all pregnant women and those with blood tests. There was no significant association between exposure status and serological result for anti-Brucella abortus IgG with adverse pregnancy outcomes. Higher odds ratios of adverse pregnancy outcomes were found in women having their first ANC visit during the first trimester, a history of preterm and low birth weight newborns.

High personal monthly income and history of abortion were associated with consumption of raw goat products, but they were found to be not significant in multiple logistic regression. The factors associated with exposure from cutaneous contacts are presented in Table 3 . Women having goats as a home animal were more likely to be exposed to goats or raw goat products by cutaneous contact with an adjusted odds ratio of 15.2 (95\% CI 9.8-26.1) and the adjusted odds ratio of women having a neighbor rearing goats was 2.0 (95\% CI 1.3-3.0).

\section{Discussion}

No evidence of association of past exposure to goats and raw goat products and the serological status of anti-Brucella abortus IgG with adverse pregnancy outcomes was found; however, a higher rate of seropositivity was found among pregnant women who had been exposed to goats or raw goat products. A history of previous preterm or low birth weight newborns were independent risk factors for adverse pregnancy outcomes. Women having goats as home animals and having a neighbour rearing goats were more likely to be exposed to goats and raw goat products by cutaneous contact.

No association was found between exposure to goats and raw goat products with adverse pregnancy outcomes in our study, which was similar to the findings of a large cohort study from Denmark, although the study designs and methodologies were different. Compared to our study, the Denmark study focused on a wide variety of animals rather than goats only, and short duration for notification of exposure collected and the study reported lower rate of cutaneous contact [32]. Although approximately one-third of the women in our study said they had been exposed to goats and raw goat products at least one time before this current pregnancy, they were less likely to be exposed during pregnancy as also found in previous studies [33-35]. According to this, the time point that we asked for retrospective women's exposure to goats and raw goat products and serum testing for IgG detection was able to explain the association with their adverse pregnancy outcomes.

No relationship between seropositivity and adverse pregnancy outcomes in our study may be explained by the study women were normal pregnant women and IgG detection representing possibly past infection in women's life. Our finding was different from the previous studies that adverse pregnancy outcomes were associated with acute infection in symptomatic pregnant women study $[8,36]$. Women with a previous preterm or low birth weight newborn had an increased risk of adverse pregnancy outcomes in their current pregnancies, as other studies have reported the same tendency [37-39].

Goat ownership and neighbors nearby rearing goats were associated with cutaneous contact with live goats or raw goat products among the study women due to the fact that animal owners are more likely to have physical contact with their own animals or the rearing environment [35, 40]. Moreover, women have more opportunity to be exposed to goats rather than other larger domestic livestock animals such as cattle or water buffalos. Goat rearing in nomadic conditions in community environments is observed in rural areas of Bangladesh, Nepal and Thailand, including our study setting in which small-scale animal production farms with poor management are common, regardless of goat ownership [34].

Exposure to goats and raw goat products was emphasized as the main interest of our study due to its influence on disease transmission and negative health consequences. Zoonotic infections which have been shown to be transmitted to pregnant women in endemic areas in previous studies include toxoplasmosis, 
Table 2 Factors associated with occurrence of any adverse pregnancy outcome among all pregnant women $(n=666)$ and those with blood tests $(n=465)$

\begin{tabular}{|c|c|c|c|c|c|c|}
\hline \multirow[t]{2}{*}{ Factor $^{a}$} & \multicolumn{3}{|c|}{$\begin{array}{l}\text { All pregnant women }(n=666) \\
\text { Adverse pregnancy outcome }(n=115)\end{array}$} & \multicolumn{3}{|c|}{$\begin{array}{l}\text { Pregnant women with blood test }(n=465) \\
\text { Adverse pregnancy outcome }(n=112)\end{array}$} \\
\hline & Crude OR $(95 \% \mathrm{Cl})$ & $\begin{array}{l}\text { Adjusted } \mathrm{OR}^{\mathrm{b}} \\
(95 \% \mathrm{Cl})\end{array}$ & $\begin{array}{l}p \text { value } \\
\text { (LR test) }\end{array}$ & Crude OR (95\% Cl) & $\begin{array}{l}\text { Adjusted } \mathrm{OR}^{\mathrm{b}} \\
(95 \% \mathrm{Cl})\end{array}$ & $\begin{array}{l}p \text { value } \\
\text { (LR test) }\end{array}$ \\
\hline \multicolumn{7}{|l|}{ Demographic characteristic } \\
\hline Age group, in years: ref. $=15-19$ & & & - & & & - \\
\hline $20-34$ & $1.3(0.6,2.5)$ & - & & $1.2(0.6,2.5)$ & - & \\
\hline $35-49$ & $1.0(0.4,2.3)$ & - & & $0.9(0.4,2.2)$ & - & \\
\hline Religion: Buddhist or others vs Muslim & $0.7(0.3,1.4)$ & - & & $1.2(0.5,2.5)$ & - & \\
\hline Education: ref. $=$ College/university or above & & & - & & & - \\
\hline Primary school or lower & $0.9(0.5,1.6)$ & - & & $0.8(0.4,1.6)$ & - & \\
\hline Secondary school & $0.9(0.5,1.6)$ & - & & $0.9(0.5,1.6)$ & - & \\
\hline Occupation: ref. = Housewife & & & - & & & - \\
\hline Agricultural worker or laborer & $1.0(0.6,1.6)$ & - & & $0.9(0.5,1.6)$ & - & \\
\hline Saleperson, teacher, clerk, or technician & $1.1(0.6,2.0)$ & - & & $0.9(0.5,1.7)$ & - & \\
\hline Personal monthly income, in USD: ref. $=0-184$ & & & - & & & - \\
\hline $185-368$ & $0.8(0.5,1.3)$ & - & & $0.8(0.5,1.2)$ & - & \\
\hline$\geq 369$ & $1.1(0.6,2.1)$ & - & & $1.1(0.5,2.2)$ & - & \\
\hline \multicolumn{7}{|l|}{ Houseshold environment } \\
\hline Having goats as home animal & $1.2(0.7,2.0)$ & - & - & $0.8(0.5,1.4)$ & - & - \\
\hline Having other home animals excluding goats & $1.4(0.9,2.1)$ & - & - & $1.5(1.0,2.3)$ & - & - \\
\hline Having neighbor rearing goats & $1.1(0.7,1.7)$ & - & - & $1.0(0.7,1.6)$ & - & - \\
\hline \multicolumn{7}{|l|}{ Obstetric information } \\
\hline $\begin{array}{l}\text { Gestational age at first antenatal care visit: } \\
1^{\text {st }} \text { trimester }(<14 \text { weeks }) \text { vs } 2^{\text {nd }} \text { trimester }(14-28 \text { weeks })\end{array}$ & $1.9(1.1,3.5)$ & $2.0(1.1,3.7)$ & 0.015 & 1. $7(0.9,3.1)$ & $1.9(1.0,3.6)$ & 0.041 \\
\hline Gravida: ref. $=$ Primi-gravida & & & - & & & - \\
\hline Multigravida & $0.8(0.5,1.2)$ & - & & $0.7(0.4,1.1)$ & - & \\
\hline Grand-multigravida & $1.0(0.5,2.1)$ & - & & $0.8(0.4,1.8)$ & - & \\
\hline Parity: ref. $=$ Nulliparity & & & - & & & - \\
\hline Primiparity & $0.8(0.5,1.3)$ & - & & $0.7(0.4,1.2)$ & - & \\
\hline Multiparity & $1.0(0.6,1.6)$ & - & & $0.9(0.5,1.5)$ & - & \\
\hline Having history of abortion & $1.0(0.6,1.8)$ & - & - & $0.8(0.5,1.5)$ & - & - \\
\hline Having history of stillbirth & $1.1(0.2,5.0)$ & - & - & $1.3(0.2,6.6)$ & - & - \\
\hline Having history of preterm birth & $3.7(1.7,7.9)$ & $2.4(1.0,5.7)$ & 0.046 & $4.1(1.7,9.8)$ & $3.6(1.4,9.3)$ & 0.010 \\
\hline Having history of low birth weight & $3.1(1.7,5.6)$ & $2.6(1.3,4.9)$ & 0.007 & $2.7(1.4,5.1)$ & $2.2(1.1,4.3)$ & 0.037 \\
\hline \multicolumn{7}{|l|}{ Exposure status - cutaneous contact } \\
\hline Live goats or goat rearing activities & $1.4(0.9,2.2)$ & - & - & $0.8(0.5,1.3)$ & - & - \\
\hline Raw goat meat & $0.7(0.3,1.6)$ & - & - & $0.5(0.2,1.1)$ & $0.4(0.2,1.0)$ & 0.035 \\
\hline Raw goat milk & $0.3(0.0,2.2)$ & - & - & $0.2(0.0,1.6)$ & - & - \\
\hline \multicolumn{7}{|l|}{ Exposure status - consumption } \\
\hline Raw goat meat & $0.8(0.3,2.2)$ & - & - & $0.6(0.2,1.6)$ & - & - \\
\hline Raw goat milk & $0.6(0.3,1.5)$ & - & - & $0.4(0.2,1.0)$ & - & - \\
\hline \multicolumn{7}{|l|}{ Serological result for anti-Brucella abortus $\lg G$} \\
\hline Positive vs negative & - & - & - & $0.2(0.0,2.0)$ & $0.2(0.0,1.4)$ & 0.041 \\
\hline
\end{tabular}

ayes vs no where reference level is no

badjusted by backward stepwise method; $O R$ odds ratios, $C l$ confidence interval of odds ratios, LR-test likelihood ratio test 
Table 3 Factors associated with having personal exposure from cutaneous contact among pregnant women $(n=666)$

\begin{tabular}{llll}
\hline Factor $^{\mathrm{a}}$ & \multicolumn{3}{l}{ Having exposure from cutaneous contact } \\
\cline { 2 - 4 } & $\begin{array}{l}\text { Crude OR } \\
(95 \% \mathrm{Cl})\end{array}$ & $\begin{array}{l}\text { Adjusted OR } \\
(95 \% \mathrm{Cl})\end{array}$ & $\begin{array}{l}p \text { value } \\
\text { (LR-test) }\end{array}$ \\
\hline $\begin{array}{l}\text { Religion: Buddhist and } \\
\text { others vs Muslim }\end{array}$ & $0.4(0.2,0.8)$ & $0.6(0.3,1.3)$ & 0.184 \\
$\begin{array}{l}\text { Having goats as } \\
\text { home animals }\end{array}$ & $14.8(9.1,24.1)$ & $15.2(8.9,26.1)$ & $<0.001$ \\
$\begin{array}{l}\text { Having other home } \\
\text { animals excluding goats }\end{array}$ & $0.7(0.5,1.0)$ & $1.5(0.9,2.3)$ & 0.100 \\
$\begin{array}{l}\text { Having neighbor } \\
\text { rearing goats }\end{array}$ & $2.7(1.9,3.9)$ & $2.0(1.3,3.0)$ & 0.002 \\
\hline
\end{tabular}

$O R$ odds ratio, $C l$ confidence interval of odds ratios, $L R$-test likelihood ratio test ${ }^{a}$ yes vs no where reference level is no

brucellosis, and coxiellosis [7, 11]. Brucella abortus is one of the common pathogens causing human brucellosis which can be found in various home animals such as cattle, goats and sheep [15, 41-43]. Our study found higher detection of anti-Brucella abortus IgG among pregnant women who were exposed to goats and raw goat products, as was also reported in studies conducted in Jordan and Afghanistan which focused on contact with unpasteurized dairy products or goat milk [11, 13]. The low seroprevalence of brucellosis among pregnant women in our study was slightly lower than studies from Yemen [44] and Pakistan [20] in which the study participants were asymptomatic pregnant women. However, our finding was lower when compared with studies conducted among slaughterhouse workers in Pakistan (21.7\%) and goat farmers and livestock officers in Thailand (8.3-8.8\%) [45, 46].

One-fourth of the women in our study reported cutaneous contact, mainly from live goats or while doing goat-rearing activities. This was likely related to ritual Islamic activities as the majority of our participants were Muslim, such as "Aqeeqah", the ritual animal sacrifice on the occasion of a new birth, and "Qurbani", the Islamic religious practice of an animal sacrifice offering to Allah [47]. Good hand hygiene practicing among people having extensive exposure to animal raising or contaminated environments and avoiding food-borne zoonosis by cooking meat well or boiling milk before consuming them should be promoted [32, 48]. For women, an explanation of the dangers involved with being around goats can be explained during ANC visits; however, a previous study found a low rate of healthcare providers gave information about hand or food hygiene for their patients who exposed to animals [49].

There were some limitations to our cohort study measuring the exposure of goats and raw goat products and seropositivity of brucellosis among pregnant women in southern Thailand. First, a history of exposure in our study included at any time before the date of the first
ANC visit for the current pregnancy, and thus recall bias may have occurred; however, these exposure events were distinctive for women. Second, only past history of infection could be diagnosed and some acute or chronic infections may have been missed because only a single serum sample was taken from each woman and the ELISA IgG test was done retrospectively thus a second sample to provide a pair of positive samples could not be tested. Third, data on smoking or drinking were not collected due to the very low rate of these habits in pregnant women in the south of Thailand. Forth, the exposure was measured cross-sectionally at one time only, during the first ANC visit, and was not rechecked during the remaining pregnancy, which may have affected the true association between exposure and adverse pregnancy outcome. Finally, women who were pregnant and aborted before coming for an ANC visit could have been missed from our study, which could have affected the results.

\section{Conclusion}

Our study found no association between past exposure with goats and/or raw goat products and adverse pregnancy outcomes, but such exposure was significantly associated with brucellosis seropositivity. Effective counseling on avoiding consumption of raw goat milk would be beneficial to prevent goat-related infection in pregnant women in our study setting.

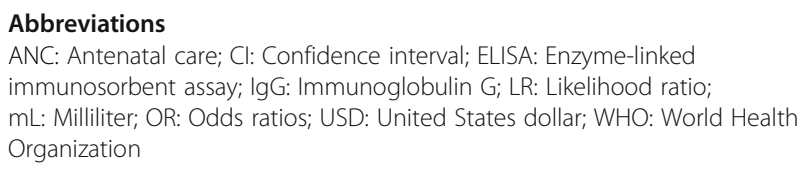
immunosorbent assay; IgG: Immunoglobulin G; LR: Likelihood ratio; mL: Milliliter; OR: Odds ratios; USD: United States dollar; WHO: World Health Organization

\section{Acknowledgements}

This study was part of the first author's thesis in partial fulfilment of the requirements for a Ph.D. at Prince of Songkla University, Thailand. The authors thank the Songkhla Provincial Public Health Office, as well as $\mathrm{Na}$ Thawee, Chana, Thepa, and Sabayoi District Public Health Offices for assisting with our contacts with District Hospitals and Health Promoting hospitals in the four study districts. The authors also acknowledge all healthcare providers, health volunteers, and laboratory workers in all study settings for their kind assistance in the collection of questionnaires, blood samples, and follow-up information.

\section{Funding}

Funding was provided by the Thailand Research Fund through the Royal Golden Jubilee PhD Program (Grant No. PHD/0098/2557, to Kan Kledmanee and Tippawan Liabsuetrakul), the National Science and Technology

Development Agency (NSTDA) of Thailand, the Graduate School Dissertation Funding, and an Excellence Center of the Epidemiology Unit Scholarship, Prince of Songkla University. The funding agencies had no involvement in study design, data collection and analysis, interpretation of data or writing the manuscript.

\section{Availability of data and materials}

The datasets of this study are not publicly available due to ethical and confidentiality reasons but are available from the corresponding author on reasonable request with the Ethics Committee's approval. 


\section{Authors' contributions}

$\mathrm{TL}$; conceived and designed the study, supervised the data collection, analyzed the data and prepared the manuscript. KK; conceived the study, conducted the data collection, analyzed the data and prepared the manuscript. SS; performed laboratory data collection, interpreted the laboratory data and reviewed the manuscript. All authors read and approved the final version of manuscript.

\section{Ethics approval and consent to participate}

The study was approved by the Research Ethics Committee of the Faculty of Medicine, Prince of Songkla University, Thailand (REC No. 58-061-15-1). Site permissions were obtained from the directors of the Provincial and District Public Health Offices for each study setting. Written consent forms were obtained from all participating pregnant women after they received a detailed oral explanation of the study. For pregnant women aged under 18 years, the consent of guardian was waived by the Research Ethics Committee.

\section{Consent for publication}

Not applicable.

\section{Competing interests}

The authors declare that they have no competing interests.

\section{Publisher's Note}

Springer Nature remains neutral with regard to jurisdictional claims in published maps and institutional affiliations.

\section{Author details}

'Epidemiology Unit, Faculty of Medicine, Prince of Songkla University, Songkhla, Thailand. ${ }^{2}$ Department of Pathology, Faculty of Medicine, Prince of Songkla University, Songkhla, Thailand.

Received: 29 November 2018 Accepted: 27 March 2019 Published online: 05 April 2019

\section{References}

1. Sather M, Fajon A-V, Zaentz R, Rubens CE. Others. Global report on preterm birth and stillbirth (5 of 7): advocacy barriers and opportunities. BMC Pregnancy Childbirth. 2010;10(Suppl 1):S5.

2. Wardlaw TM, World Health Organization, UNICEF, editors. Low birthweight: country, regional and global estimates. Geneva. New York: WHO; UNICEF; 2004. p. 27

3. Kramer MS, Zhang X, Platt RW. Analyzing risks of adverse pregnancy outcomes. Am J Epidemiol. 2014;179(3):361-7.

4. Baud D, Peter O, Langel C, Regan L, Greub G. Seroprevalence of Coxiella burnetii and Brucella abortus among pregnant women. Clin Microbiol Infect. 2009;15(5):499-501.

5. Baud D, Greub G. Intracellular bacteria and adverse pregnancy outcomes. Clin Microbiol Infect. 2011;17(9):1312-22.

6. Goldenberg RL, McClure EM, Saleem S, Reddy UM. Infection-related stillbirths. Lancet. 2010;375(9724):1482-90.

7. Nielsen SY, Mølbak K, Henriksen TB, Krogfelt KA, Larsen CS, Villumsen S. Adverse pregnancy outcomes and Coxiella burnetii antibodies in pregnant women, Denmark. Emerg Infect Dis. 2014;20(6):925-31.

8. Elshamy M, Ahmed IA. The effects of maternal brucellosis on pregnancy outcome. J Infect Dev Ctries. 2008;2(3):230-4.

9. Salcedo SP, Chevrier N, Lacerda TLS, Ben Amara A, Gerart S, Gorvel VA, et al. Pathogenic Brucellae replicate in human trophoblasts. J Infect Dis. 2013; 207(7):1075-83.

10. Fernández AG, Ferrero MC, Hielpos MS, Fossati CA, Baldi PC. Proinflammatory response of human trophoblastic cells to Brucella abortus infection and upon interactions with infected phagocytes. Biol Reprod. 2016;94(2):1-11

11. Akbarian Z, Ziay G, Schauwers W, Noormal B, Saeed I, Qanee AH, et al. Brucellosis and Coxiella burnetii infection in householders and their animals in secure villages in Herat province, Afghanistan: a cross-sectional study. PLoS Negl Trop Dis. 2015;9(10):1-17.

12. Corrao CRN, Mazzotta A, La Torre G, De Giusti M. Biological risk and occupational health. Ind Health. 2012;50(4):326-37.

13. Abo-Shehada MN, Abu-Halaweh M. Risk factors for human brucellosis in northern Jordan. East Mediterr Health J. 2013;19(2):135-40.
14. Frimpong C, Makasa M, Sitali L, Michelo C. Seroprevalence and determinants of toxoplasmosis in pregnant women attending antenatal clinic at the university teaching hospital, Lusaka, Zambia. BMC Infect Dis. 2017:17(10):1-8.

15. Corbel MJ. Brucellosis in humans and animals. Food and agriculture Organization of the United Nations, World Health Organization, world organisation for animal health. Geneva: WHO; 2006.

16. Kurdoglu M, Adali E, Kurdoglu Z, Karahocagil MK, Kolusari A, Yildizhan R, et al. Brucellosis in pregnancy: a 6-year clinical analysis. Arch Gynecol Obstet. 2010;281(2):201-6.

17. Vilchez G, Espinoza M, D'Onadio G, Saona P, Gotuzzo E. Brucellosis in pregnancy: clinical aspects and obstetric outcomes. Int J Infect Dis. 2015:38:95-100.

18. Abo-Shehada MN, Abu-Halaweh M. Seroprevalence of Brucella species among women with miscarriage in Jordan. East Mediterr Health J. 2011 17(11):871-4.

19. Rujeni N, Mbanzamihigo L. Prevalence of brucellosis among women presenting with abortion/stillbirth in Huye, Rwanda. J Trop Med. 2014;2014:1-3.

20. Ali S, Akhter S, Neubauer H, Scherag A, Kesselmeier M, Melzer F, et al. Brucellosis in pregnant women from Pakistan: an observational study. BMC Infect Dis. 2016;16(1):468.

21. Nassaji M, Rahbar N, Ghorbanı R, Lavaf S. The role of Brucella infection among women with spontaneous abortion in an endemic region. J TurkGer Gynecol Assoc. 2008;9(1):20-3.

22. Çelebi G, Külah C, Kiliç S, Üstündağ G. Asymptomatic Brucella bacteraemia and isolation of Brucella melitensis biovar 3 from human breast milk. Scand Infect Dis. 2007;39(3):205-8.

23. Hewitt WG, Payne DJ. Estimation of IgG and IgM brucella antibodies in infected and non-infected persons by a radioimmune technique. J Clin Pathol. 1984:37(6):692-6.

24. El-Mohammady H, Shaheen HI, Klena JD, Nakhla IA, Weiner MA, Armstrong AW. Specific IgA antibodies in the diagnosis of acute brucellosis. J Infect Dev Ctries. 2012;6(2):192-200

25. Deslandes V, Antonation K, Jessamine P, Toye B, Cooper C, Patel S. Incidental post-partum isolation of Brucella melitensis in an asymptomatic woman. Off J Assoc Med Microbiol Infect Dis Can. 2018:1-4.

26. Weerakiet S, Pongthai S, Suthutvoravut S. Spontaneous abortion rate. J Med Assoc Thail. 1996;79(4):249-52.

27. Chawanpaiboon S, Kanokpongsakdi S. Preterm birth at Siriraj hospital: a 9year period review (2002-2010). Siriraj Med J. 2011:63(5):143-6.

28. Kahn LH. Confronting zoonoses, linking human and veterinary medicine. Emerg Infect Dis. 2006;12(4):556.

29. Ninprom T, Nonthasorn P, Thiptara A, Kongkaew W. Prevalence and spatial distribution of brucellosis in goats in the southernmost provinces of Thailand in 2014. Thai NIAH EJournal. 2016;11(2):16-26.

30. Songkhla Provincial Livestock Office. Number of goats and households with goats in Songkhla by districts in 2014. http://pvlo-sgk.dld.go.th/webnew/ images/stories/2557.xls. Accessed 15 July 2016.

31. Nielsen SY, Molbak K, Andersen AMN, Brink Henriksen T, Kantsø B, Krogfelt KA, et al. Prevalence of Coxiella burnetii in women exposed to livestock animals, Denmark, 1996 to 2002. Eurosurveillance. 2013;18(28):1-8.

32. Nielsen SY, Henriksen TB, HjøLlund NH, MøLbak K, Andersen AMN. Risk of adverse pregnancy outcome in women exposed to livestock: a study within the Danish National Birth Cohort. Epidemiol Infect. 2014;142(07):1545-53.

33. Kendall P, Medeiros LC, Hillers V, Chen G, Dimascola S. Food handling behaviors of special importance for pregnant women, infants and young children, the elderly, and immune-compromised people. J Am Diet Assoc. 2003;103(12):1646-9.

34. Penakalapati G, Swarthout J, Delahoy MJ, McAliley L, Wodnik B, Levy K, et al. Exposure to animal feces and human health: a systematic review and proposed research priorities. Environ Sci Technol. 2017:51(20):11537-52.

35. Weng H-Y, Ankrom K. Practices and perceptions of animal contact and associated health outcomes in pregnant women and new mothers. Front Vet Sci. 2016:3(5):1-7.

36. Aydın B, Beken S, Akansel R, Dilli D, Okumuş N, Zenciroğlu A, et al. Prematurity due to maternal brucella infection and review of the literature. Turk J Pediatr. 2013;55:433-7.

37. Bhattacharya S, Townend J, Shetty A, Campbell D, Bhattacharya S. Does miscarriage in an initial pregnancy lead to adverse obstetric and perinatal outcomes in the next continuing pregnancy? BJOG Int J Obstet Gynaecol. 2008;115(13):1623-9. 
38. Singh D, Goli S, Parsuraman S. Association between obstetric complications \& previous pregnancy outcomes with current pregnancy outcomes in Uttar Pradesh, India. Indian J Med Res. 2014;139(1):83-90.

39. Kujala S, Waiswa P, Kadobera D, Akuze J, Pariyo G, Hanson C. Trends and risk factors of stillbirths and neonatal deaths in eastern Uganda (1982-2011): a cross-sectional, population-based study. Tropical Med Int Health. 2017;22(1):63-73.

40. Kifle YW, Goeyvaerts N, Van Kerckhove K, Willem L, Faes C, Leirs H, et al. Animal ownership and touching enrich the context of social contacts relevant to the spread of human infectious diseases. Barrat a, editor. PLoS One. 2015;10(7):1-13.

41. Ali S, Akhter S, Neubauer H, Melzer F, Khan I, Ali Q, et al. Serological, cultural, and molecular evidence of Brucella infection in small ruminants in Pakistan. J Infect Dev Ctries. 2015;9(05):470.

42. Behroozikhah AM, Bagheri Nejad R, Amiri K, Bahonar AR. Identification at biovar level of Brucella isolates causing abortion in small ruminants of Iran. J Pathog. 2012:2012:1-4.

43. Wareth G, Melzer F, Tomaso H, Roesler U, Neubauer H. Detection of Brucella abortus DNA in aborted goats and sheep in Egypt by real-time PCR. BMC Res Notes. 2015;8(1):1-5.

44. Al-Arnoot S. Seroprevalence of Brucella infection among pregnant women in Sana'a city, Yemen. Biom Biostat Int J. 2018;7(5):445-51.

45. Te-Chaniyom T, Geater AF, Kongkaew W, Chethanond U, Chongsuvivatwong V. Goat farm management and Brucella serological test among goat keepers and livestock officers, 2011-2012, Nakhon Si Thammarat Province, southern Thailand. One Health. 2016;2:126-30.

46. Mukhtar F. Brucellosis in a high risk occupational group: seroprevalence and analysis of risk factors. J Pak Med Assoc. 2010;60(12):4

47. Semae $\mathrm{S}$. The success way of goat raising by Muslim way. I Yala Rajabhat Univ. 2007;2(1):72-81.

48. Wright JG, Jung S, Holman RC, Marano NN, McQuiston JH. Infection control practices and zoonotic disease risks among veterinarians in the United States. JAVMA. 2008:232(12):1863-72.

49. Kersting AL, Medeiros LC, LeJeune JT. Zoonoses and the physicians' role in educating farming patients. J Agromedicine. 2009;14(3):306-11.

Ready to submit your research? Choose BMC and benefit from:

- fast, convenient online submission

- thorough peer review by experienced researchers in your field

- rapid publication on acceptance

- support for research data, including large and complex data types

- gold Open Access which fosters wider collaboration and increased citations

- maximum visibility for your research: over $100 \mathrm{M}$ website views per year

At $\mathrm{BMC}$, research is always in progress.

Learn more biomedcentral.com/submissions 